\title{
Species Composition of Benthic Diatoms and Distribution of Chlorophyll a on an Intertidal Flat in the Dutch Wadden Sea
}

\author{
Franciscus Colijn ${ }^{1}$ and Kees S. Dijkema ${ }^{2}$ \\ ${ }^{1}$ Department of Systematic Botany, Biological Centre of the University of Groningen, Kerklaan 30, Haren, The Netherlands \\ ${ }^{2}$ Rijksinstituut voor Natuurbeheer, P. O. B. 59, Texel, The Netherlands
}

\begin{abstract}
A linear transect with 12 sampling points was sampled in a tidal estuarine environment during 1973 for chlorophyll $a$ and pheophytin, and for species composition of epipelic diatoms. A gradual pattern in sediment from coarse to fine was found from the most seaward station towards the most landward station of the transect. Differences in station level gave emersion times of 37 to $67 \%$ of the tidal cycle. In the course of the year, fluctuations in chlorophyll a content (mg chlorophyll a $\mathrm{m}^{-2}$ in the top $2 \mathrm{~cm}$ of the sediment) appeared to be distinctly parallel at all stations. However, mean yearly values differed widely from station to station, ranging between 20 and $100 \mathrm{mg}$ chlorophyll $\mathrm{a} \mathrm{m}^{-2}$. Chlorophyll a concentration was positively related to the amount of particles $<16 \mu \mathrm{m}$ in the sediment; this proportion was considered to relate negatively to the degree of exposure to currents and wave action. It is likely that low daily winter irradiances limited diatom growth. Heavy rain and strong wave action during storms suddenly reduced the chlorophyll a content considerably. Species composition of epipelic benthic diatoms could partly be related to the sediment gradient and time of year. It seems that high biomass values are formed almost exclusively by single species which are indifferent in their spatial distribution.
\end{abstract}

\section{INTRODUCTION}

This study forms part of a research program investigating the effects of the discharge of organic waste water into the Ems-Dollard estuary (The Netherlands) (De Wolf, 1977). The program includes phycological, microbiological, zoological and hydrographical research. This paper considers the influence of some abiotic factors on the presence of algal pigments as a measure of algal biomass and the species composition of epipelic diatoms along a transect over an intertidal flat.

Colijn and Koeman (1975) found, in another part of the Wadden Sea, a distinct distributional pattern of 'frustule assemblages', consisting of both living and dead diatom cells, related to different habitat types. In their study, sampling was limited to the summer. The present study lasted almost a year; it paid attention to spatial and temporal variations in species composition. Most studies on vegetations of micro-phytobenthos concern either primary production (Grøntved, 1960;

Contribution No. 38 of the research group 'Biological Investigation of the Ems-Dollard estuary
Leach, 1970; Marshall et al., 1971; Cadée and Hegeman, $1974 \mathrm{a}, 1977$ ) or the species composition of the diatom fraction (Hustedt, 1939; Brockmann, 1950; Colijn and Koeman, 1975). This study attempts to relate both biomass- dependent data and species composition to the environmental factors measured; it includes results of a study by Dijkema (1975). The use of cluster and factor analysis (Holland and Claflin, 1975) for the description of species composition in algal vegetations makes it possible to deal with large data sets; the actual analysis was facilitated by employing computers.

\section{MATERIAL AND METHODS}

\section{Sampling}

The transect (see section 'Geography') was sampled 26 times in 1973 during low tide. In the first half of 1973 samples were taken weekly, later monthly up to November.

At each station, 3 sediment cores of $1 \mathrm{~cm}^{2}$ and $2 \mathrm{~cm}$ depth were taken for pigment analysis with a perspex 
Table 1. Reliability of sampling procedure. The mean of 10 random samples obtained at 4 stations is compared with the mean of subjectively chosen samples. The latter procedure was used in this study

\begin{tabular}{|ccrr|}
\hline $\begin{array}{c}\text { Date } \\
\text { (Station) }\end{array}$ & $\begin{array}{c}\text { Pigment } \\
\left(\mathrm{mg} \mathrm{m}^{-2}\right)\end{array}$ & $\begin{array}{c}\text { Mean of random } \\
\text { samples (n=10) }\end{array}$ & $\begin{array}{c}\text { Mean of subjectively } \\
\text { chosen samples (n=3) }\end{array}$ \\
\hline $5-\mathrm{III}$ & chlor. & $43.8(33.7-52.9)$ & 54.3 \\
$(10)$ & pheo. & $49.7(41.9-57.5)$ & 41.9 \\
$29-\mathrm{V}$ & chlor. & $168.1(138.9-197.3)$ & 152.4 \\
$(8)$ & pheo. & $255.0(203.2-306.9)$ & 306.1 \\
$29-\mathrm{V}$ & chlor. & $73.0(54.7-91.3)$ & 66.8 \\
$(10)$ & pheo. & $79.0(66.8-91.2)$ & 64.8 \\
$29-\mathrm{V}$ & chlor. & $104.8(84.4-125.2)$ & 66.8 \\
$(12)$ & pheo. & $445.0(334.3-545.7)$ & 402.8 \\
& & & \\
Confidence limits for $\mathrm{P}=95 \%$ & & & \\
\end{tabular}

core - one from a rich, one from an average and one from a poor diatom vegetation patch, as judged by eye from the intensity of the coloration of the sediment surface. The cores were extracted separately with $90 \%$ aqueous aceton. The pigment content of the extracts was measured according to Lorenzen (1967). All values

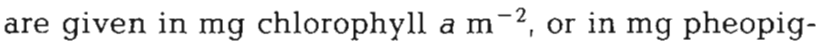
ment $\mathrm{m}^{-2}$, according to the equations

$$
\frac{A \times K \times(E 664-E 664 a) \times v \times 10}{0 \times I}
$$

or

$\frac{A \times K(R \times E 664 a-E 664) \times v \times 10}{0 \times 1}$

where $A, R$ and $K$ are constants as defined by Lorenzen, $v$ is the volume of aceton (ml), E 664 the extinction at $664 \mathrm{~nm}$ before acidification, E 664 a the extinction at $664 \mathrm{~nm}$ after acidification, 0 the sample surface $\left(\mathrm{cm}^{2}\right)$ and $l$ the optical path length $(\mathrm{cm})$. No corrections for turbidity at $750 \mathrm{~nm}$ could be made on the colorimeter used.

The sampling procedure for pigment analysis was tested 4 times. From a $10 \times 10 \mathrm{~m}$ plot, 10 samples were taken at random. The results (Table 1) were compared with the above-described standard procedure. Not all means of the subjectively taken samples were within the $95 \%$ confidence limits for the random samples, due to the patchy distribution of the microphytobenthos - a phenomenon already referred to by others (e.g. Cadée and Hegeman, 1974a; Colijn and Van Buurt, 1975). For analysis of the diatom flora, sediment samples were scraped from the sediment surface at Stations 2, 4, 6, 8, 10, 12, and 13. The lens-tissue technique (Eaton and Moss, 1966; Sullivan, 1975) was used; hence only positively phototactic diatoms were obtained. The living flora investigated by this method includes only part of the living species present (Colijn et al., 1976; De Jonge, 1979).

The top $2 \mathrm{~cm}$ of the sediment was sampled once (15-
III) for analysis of grain-size distribution, determined by the Rijksdienst voor de Ijsselmeerpolders at Baflo (Essink, 1978). The results are presented in Table 2. Water content of the sediment was determined 7 times at all stations by wet and dry-weight measurement (Linke, 1939). At all stations, surface sediments were analysed 4 times (17-I, 27-II, 14-III, 27-VI) for organic carbon according to Walkley and Black (1934). Depth of the reduced layer was measured twice (15-V, 27-VI) at all stations. Sediment temperature was determined for each sampling date at Station 3 in the top $\mathrm{cm}$.

\section{Research on Diatom Species}

The diatoms obtained with the lens-tissue technique were cleaned using a $30 \% \mathrm{H}_{2} \mathrm{O}_{2}$ solution. After several washings the diatom suspensions were pipetted onto cover slips and, after drying, embedded in Clearax mounting medium. For each slide 150 to 500 frustules were identified. The relative abundances of the species were expressed as percentages of the total number of frustules counted. Values smaller than $1 \%$ were neglected for further analysis. The data are summarized in a synoptic table (Table 3), employed in terrestrial phytosociology (Den Held and Den Held, 1973; Westhoff and Van der Maarel, 1973). Each sample was treated as a phytosociological relevee. The total amount of relevees was 65 ( 7 stations, which were sampled 9 times +2 added in May). For clarity of arrangement the abundances of the species are presented by bars of different size.

Sampling stations were rearranged according to the proportion of the sediment fraction smaller than $16 \mu \mathrm{m}$, as measured on 15-III, resulting in a sequence $2,4,6$, $10,8,13,12$ from sand to sandy mud (Tables 2 and 3 ). For the same reason of clarity the stations are summarized in 3 groups (1: Stations 2, 4; 2: Stations 6, 10, 8 , 13; 3 : Station 12) according to their sediment composition: sand, muddy sand and sandy mud respectively. 
The species were arranged in such a way that distinct groups (Ia-IVb) could be recognized (Table 3 ). Species abundances were used to calculate similarity coefficients according to Jaccard (cf. Goodall, 1973a; Colijn and Koeman, 1975), and an agglomerative centroid cluster analysis (Goodall, 1973b; Colijn and Koeman, 1975) was used to classify the relevees. This procedure is referred to as 'quantitative cluster analysis'. A second cluster analysis was carried out with the same methods - only considering the presence of the species and neglecting the abundances - termed the 'qualitative' cluster analysis. Both analyses are given in dendrograms (Figs 7 and 8). For each of the clusters composing the dendrogram of Figure 7 , 'dominant' species as well as 'frequent' species were determined. Species occurring in more than half of the relevees of a cluster with an abundance of $>10 \%$ were termed dominant; those occurring in more than half of the relevees, frequent (Table 4).

\section{Geography}

In the Eastern part of the Dutch Wadden Sea (Figs 1, 2) a linear transect was marked every $200 \mathrm{~m}$. This resulted in 13 permanent sampling stations. The transect was chosen in such a way that obvious environmental gradients could be expected; it runs from the large tidal channel Oude Westereems to the coast where land reclamation is progressing. From the channel to the coast the sediment changes from sandy to muddy (Table 2) whilst the exposure changes from exposed to sheltered. A relative degree of exposure was derived from the ripple structure of the sediment surface. The permanent sampling stations (Fig. 2) were leveled and a profile was drawn (Fig. 4B). Using the mean tidal curve the mean emersion time was calculated for each of the stations (Fig, 4A). For each station the mean emersion time is given in Table 2.

Weather conditions are summarized in Figure 3. Most data have been obtained from the monthly surveys published by the Royal Dutch Meteorological Office at Station Eelde; wind direction, wind force and tidal deviations were obtained from own recordings. Surface water temperatures were measured in the Oude Westereems at $0.5 \mathrm{~m}$ water depth. Salinity was measured by Manuels and Rommets (1973) in the nearby tidal channels; it amounted to ca $29 \% \mathrm{~S}$.

Stations 2, 3, 4, and 5 (Figs 2, 4B) were all situated on one shoal and influenced directly by the large water masses of the Oude Westereems. These stations are scoured by tidal currents and are exposed to wash of the waves. This results in a rippled sandy sediment. Station 6 was situated on the south slope of the above mentioned shoal and therefore less exposed to currents

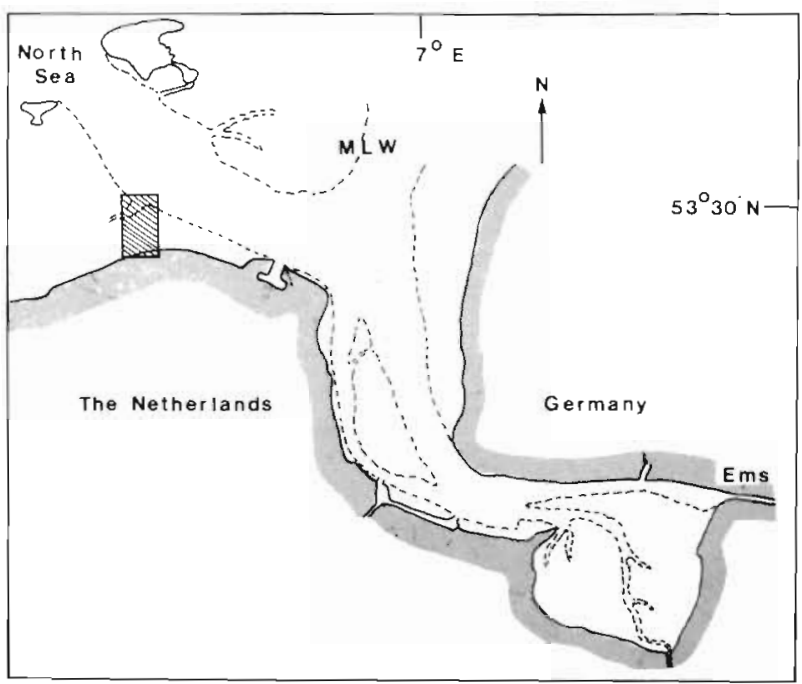

Fig. 1. Ems-Dollard estuary with approximate position of sampled transect (shaded insert). MLW: mean low water mark

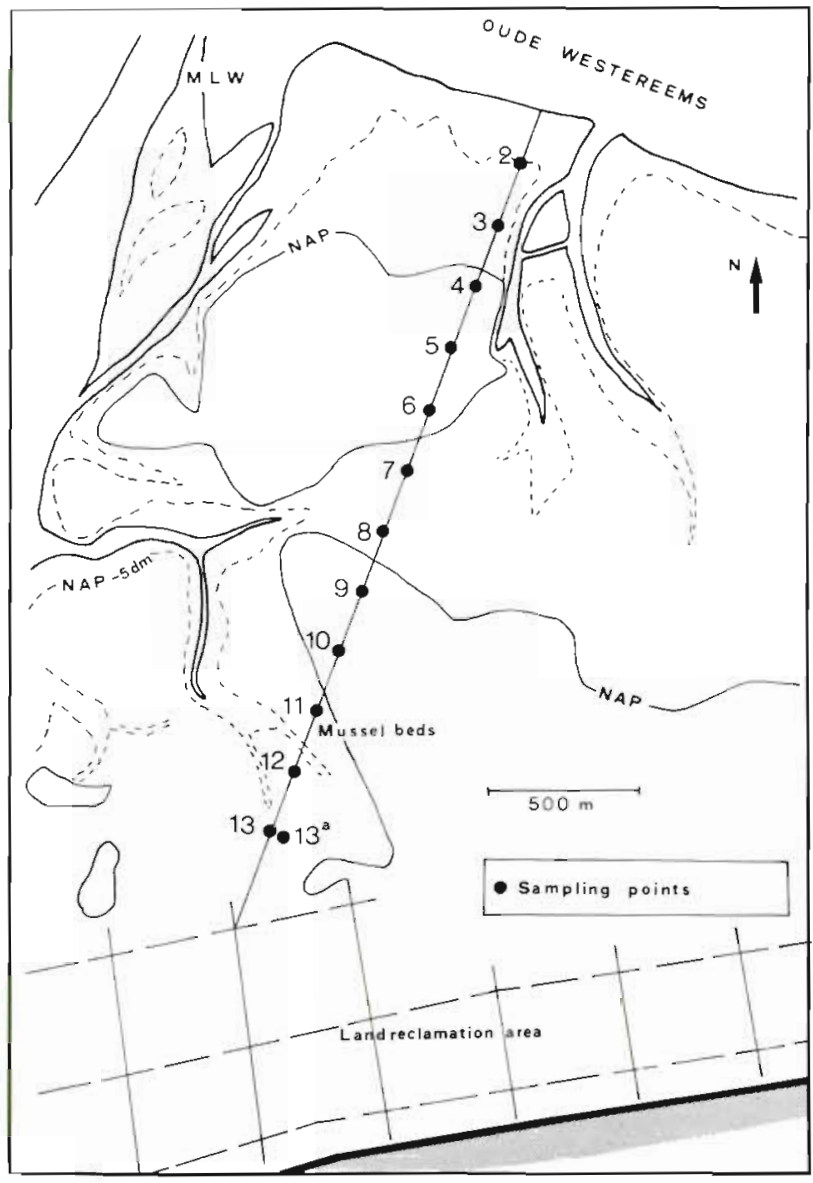

Fig. 2. Position of sampling points along transect. Contour lines reveal topography of surounding area. MLW: mean low water mark ( $13 \mathrm{dm}$ below NAP); NAP: New Ansterdam Level 
Table 2. Small particle fraction $(<16 \mu \mathrm{m}$ ) (expressed as percentual weight fractions) and mean emersion time (percentage emersion of total tidal period) at each station along the transect

\begin{tabular}{|ccc|}
\hline Station & $\begin{array}{c}\text { Small particle } \\
\text { fraction }\end{array}$ & $\begin{array}{c}\text { Mean emersion } \\
\text { time }\end{array}$ \\
\hline 2 & 4.4 & 37 \\
3 & 4.4 & 46 \\
4 & 4.6 & 55 \\
5 & 4.7 & 67 \\
6 & 6.2 & 57 \\
7 & 9.6 & 49 \\
8 & 7.2 & 49 \\
9 & 6.5 & 55 \\
10 & 5.9 & 67 \\
11 & 14.4 & 46 \\
12 & 15.4 & 40 \\
13 & 7.9 & 49 \\
\hline
\end{tabular}

and waves. The sediment contained a higher percentage of small particles than did Stations 2 to 5 (Table 2).

Stations 7 and 8 remained covered by a $5-10 \mathrm{~cm}$ deep water layer during low tide, because they were both situated in a depression. The silt content was higher than on the more elevated Stations 6 and 9 .

Stations 9 and 10 were situated on a narrow extension of a high shoal, where we could see fine particles settle during periods of calm weather.

Stations 11 and 12 were situated on both sides of a tidal creek with several mussel beds. The activity of these mussels promote the sedimentation of small particles in this region.
Station 13 was in the direct neighbourhood of a landreclamation area. The vicinity of small creeks caused a coarser sediment composition than at Stations 11 and 12. After the end of March Station 13 a was sampled because the diversion of a creek made sampling at the original station impossible.

The sediment composition, measured only once (15-III) gives an impression of the relative distribution of the sediment fraction $<16 \mu \mathrm{m}$ along the transect. Temporal variations exist; this was also shown for 3 stations in the Eastern Wadden Sea (Colijn, 1974). However, such temporal changes have a smaller order of magnitude than the differences in sediment composition observed between our stations (cf. Essink, 1978).

The water content of the sediment proved to be positively related to the proportion of the $<16 \mu \mathrm{m}$ fraction (Fig. 5A). Maximum values (up to $40 \%$ ) were found for the lower sheltered stations $(7,8,11,12)$; these stations also featured the highest carbon contents, ranging from 1.5 to $7.5 \mathrm{~g} \mathrm{C} \mathrm{kg}^{-1}$ dry sediment.

The relationship between the $<16 \mu \mathrm{m}$ fraction and the $\mathrm{C}$ content is illustrated in Figure 5B (cf. Essink, 1978, p. 54). At Stations 2, 3, and 4 the reduced horizon (grey or black layer) was found at a depth of ca $10 \mathrm{~cm}$; at Stations 5 to 13, at a depth of 1 to $4 \mathrm{~cm}_{\text {; }}$ in summer the reduced layer approached - but never reached the surface at the actual sampling points.

Sediment surface temperatures are compiled in Figure 3 ; they were in agreement with values reported by others (Linke, 1939; Colijn, unpubl.).

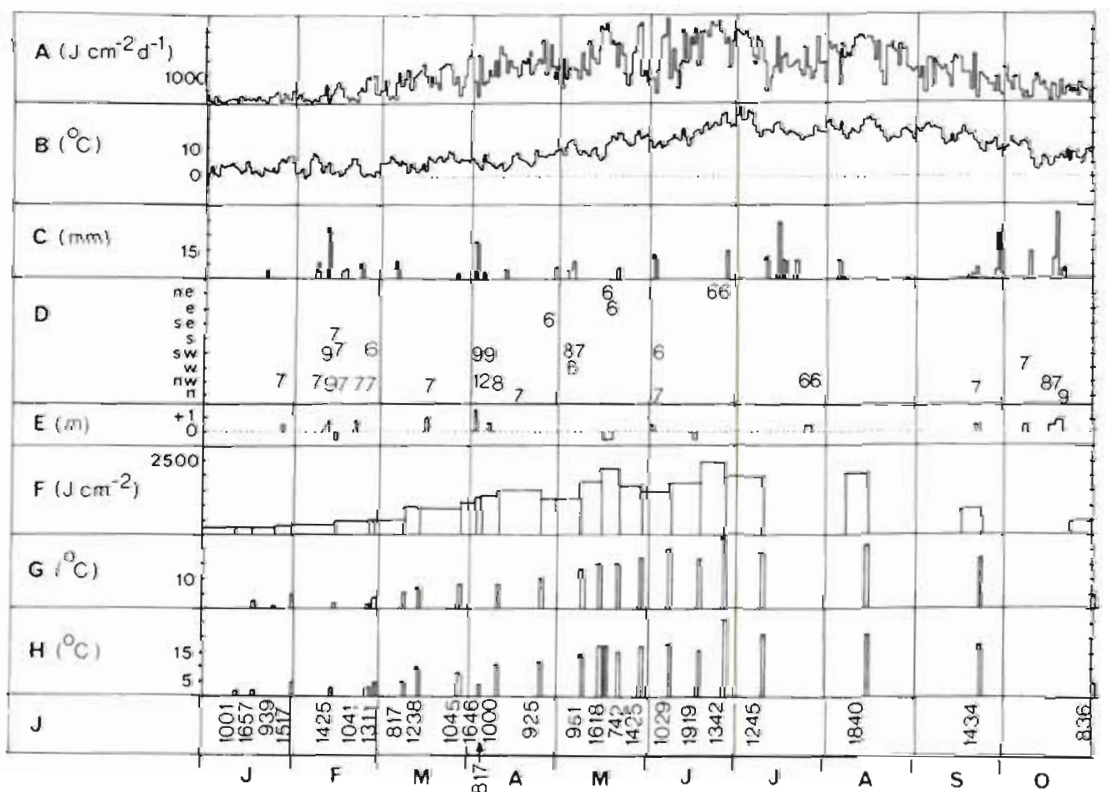

Fig. 3. Seasonal variation of environmental conditions. A: global radiation; B: mean air temperature; C: precipitation (if exceeding $5 \mathrm{~mm}$ ); D: wind direction and wind force (Beaufort scale, above 5 only); $E$ : deviation of normal tidal level; F: total global radiation between sampling days; $G$ : water temperatures as measured in Oude Westereems; $H$ : sediment temperature at Station 3; J: time of low water ( $=$ approximate time of sampling) 

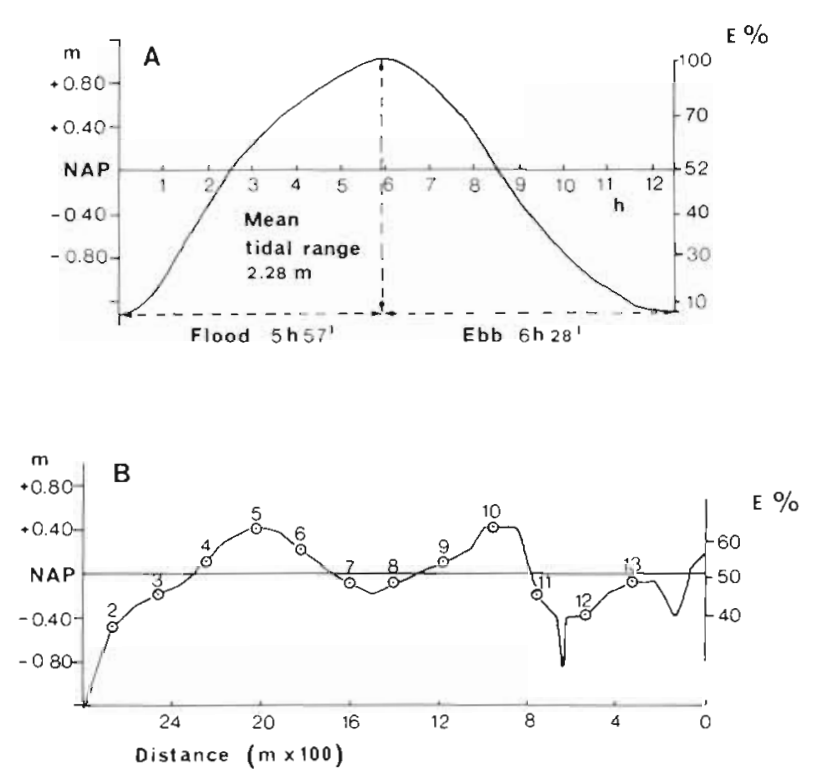

Fig. 4 A: Mean tidal curve and emersion time $(E=\%$ of tidal cycle). B: Level of sampling stations and emersion time; distance from land reclamation area (Fig. 2); NAP: New Amsterdam Level

\section{RESULTS}

\section{Algal Pigment Concentrations}

The spatial distribution of chlorophyll a (Figs 6 and 7) reveals low concentrations on the exposed sandy stations (2 to 5 ) and maximum concentration on the more sheltered stations $(7,8,9)$. The seasonal fluctuation of chlorophyll a was very much alike for all stations; it showed characteristic features. The low values in winter were followed by a spring bloom, starting in March. Subsequently, a sudden decrease occurred during the first week of April. A maximum was reached in May and June. After a distinct summer depression (July) a new maximum was attained at Stations 8 and 9 in autumn; at that time, the other stations showed almost constant values.

The pheopigment concentrations showed roughly the same spatial and temporal distributions as did the chlorophyll a concentrations (Figs 6 and 7). However, at the most exposed stations (2 to 5), pheopigment concentrations were lower than the chlorophyll a concentrations; whereas at the sheltered stations $(7,8)$ and at the most landward stations $(11,12,13$ a) pheopigment concentrations were much higher than the chlorophyll a concentrations. A positive relation between pheopigment concentration and the $<16 \mu \mathrm{m}$ sediment fraction was found (Fig. 5C).

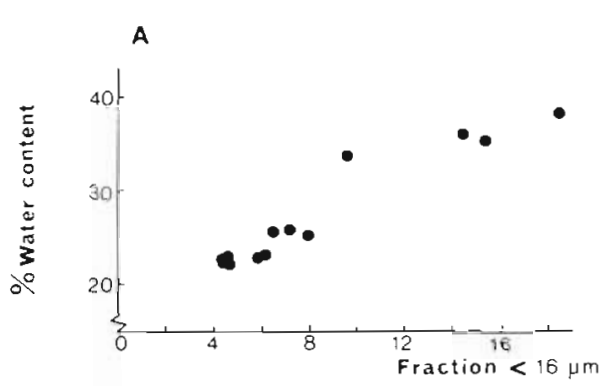

B
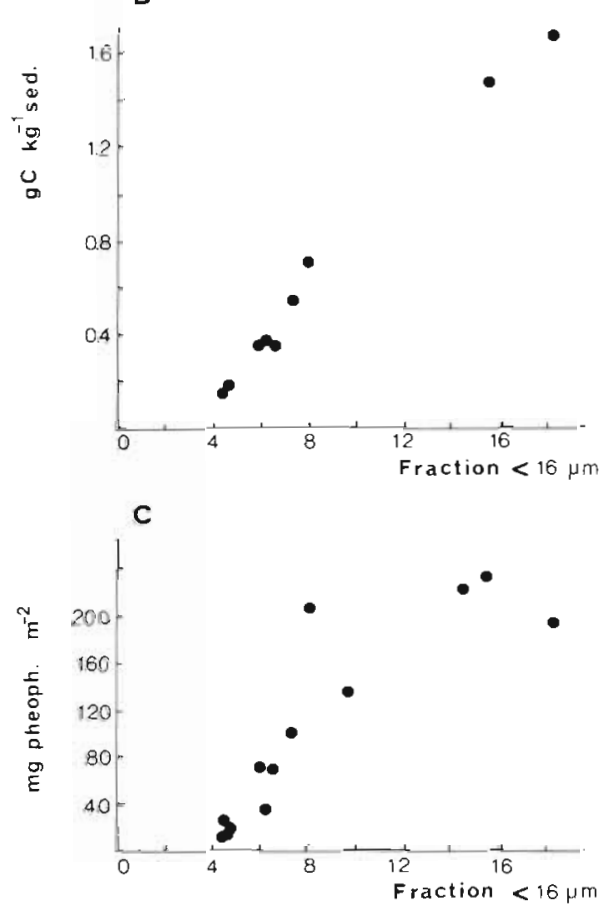

Fig. 5 A: Relation between sediment fraction $<16 \mu \mathrm{m}$ and water content. B: Relation between sediment fraction $<16 \mu \mathrm{m}$ and carbon content. C: Relation between sediment fraction $<16 \mu \mathrm{m}$ and pheophytin concentration. All data from samples obtained on 14-III-1973. Water content and sediment fraction $<16 \mu \mathrm{m}$ both expressed as \% of dry weight; carbon content as

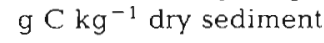

\section{Epipelic Species Composition}

Table 3 distinguishes 4 categories of species with different distributional patterns along the sediment gradient. Of these 4 categories, 3 are limited to a distinct combination of stations (Categories I-III), and 1 (Category IV) is not limited at all. The 4 categories have been subdivided into 2 groups. The first group (a) includes species without a temporal distribution, the second (b) species with a pronounced temporal distribution.

The similarity coefficients calculated for the relevees and the dendrograms drawn resulted in the distinction 
Table 3. Synopsis. Stations summarized in 3 groups: Group 1 on sand (Stations 2, 4); 2 on muddy sand (Stations $6,10,8,13) ; 3$ on sandy mud (Station 12). Explanation of arrangement of stations and species in the text. Bars of different size indicate mean abundances of $1 \%$ (interrupted line), $2-5 \%, 6-10 \%, 11-25 \%, 26-50 \%$ and $51-100 \%$, respectively

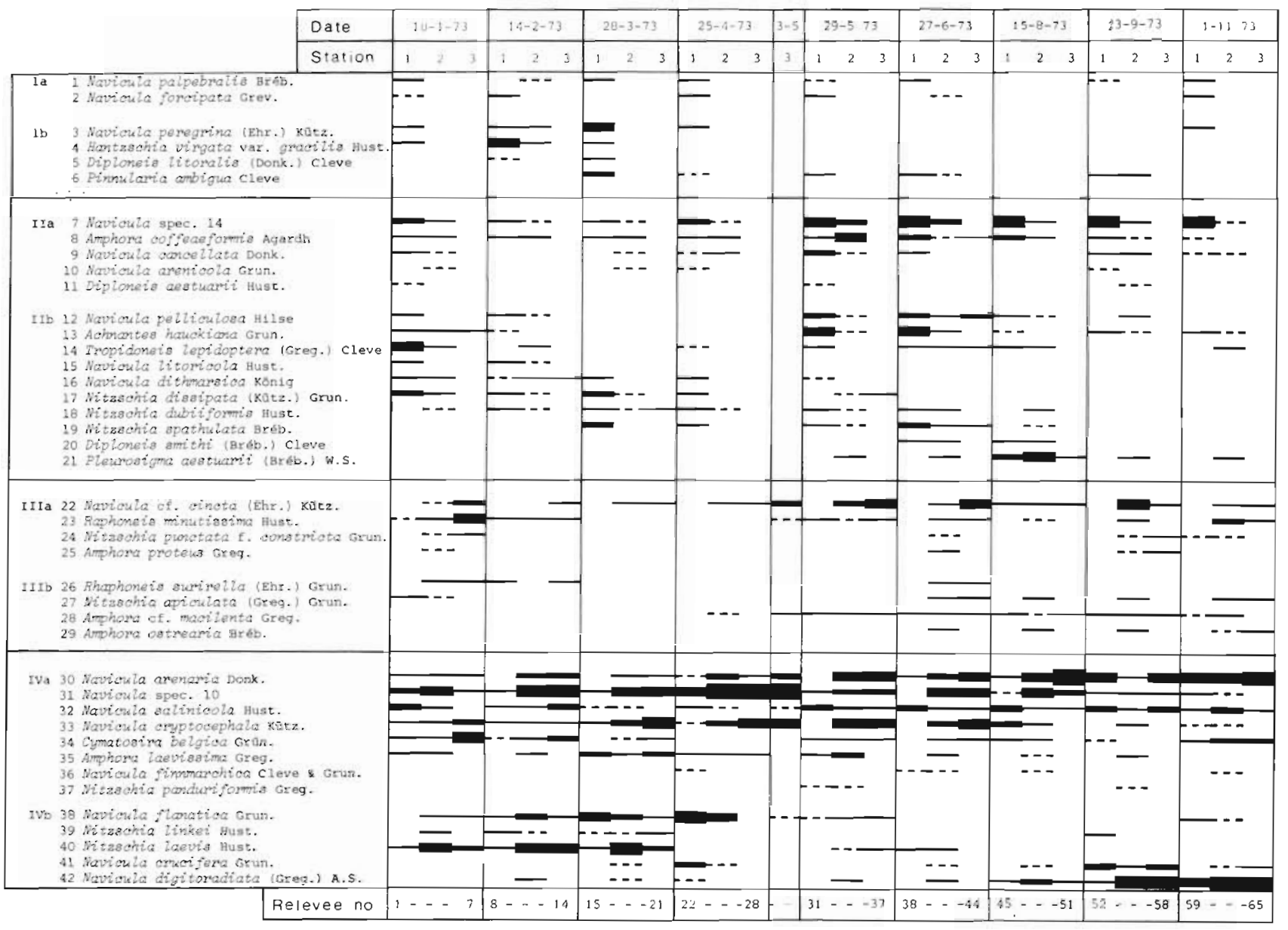

Table 4. Species composition of Clusters A to I, based on quantitative cluster analysis. Numbers in brackets: numbers of relevees per cluster; for species names pertaining to these numbers and for species listed in the 4 columns (Categories I to IV) consult Table 3. Boxes: number of dominant species (present in more than half of the relevees of a cluster with an abundance of $>$ $10 \%$. Circles: number of frequent species (present in more than half of the relevees). All other numbers: upper horizontal line $=$ number of relevers in which a given species occurred; lower horizontal line: occurrence of a species with an abundance $>10 \%$

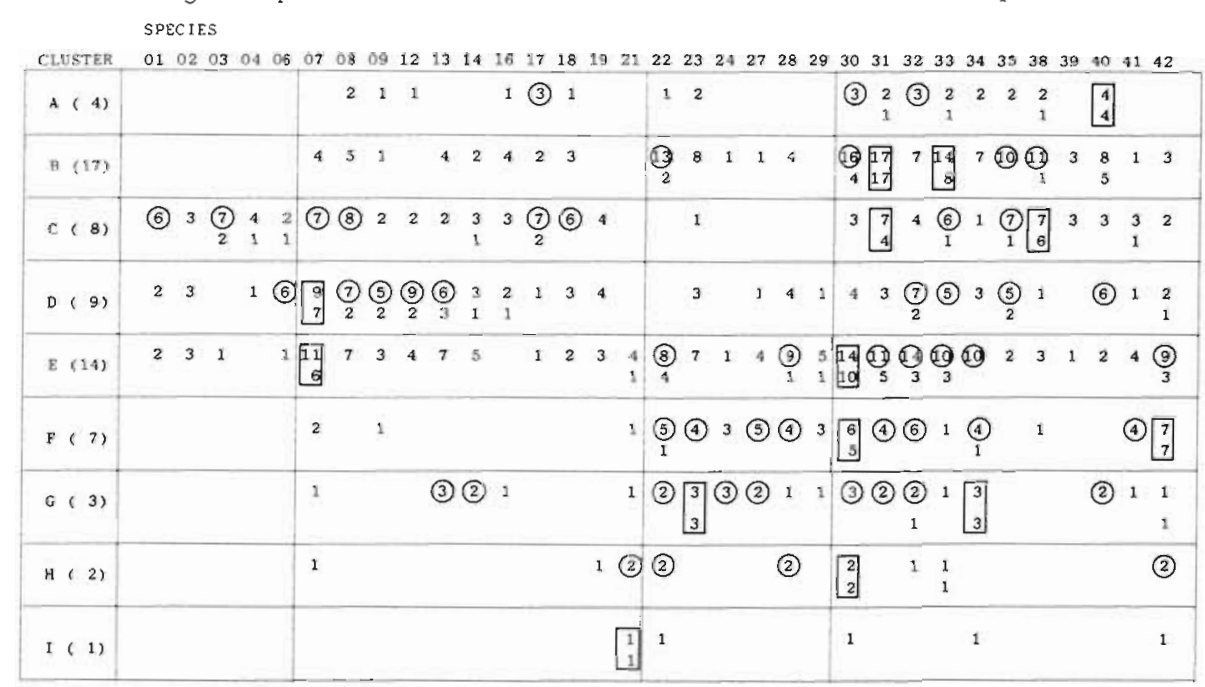


of 9 clusters (Fig. 8) in the quantitative cluster analysis, and 6 clusters (Fig.9) in the qualitative cluster analysis. The species composition of the clusters is given for the quantitative analysis only (Table 4). This table lists the species which dominate a cluster; although an overlap in species composition occurs, a combination of the most frequent and most dominant species can be found for each cluster. In these clusters, species of Category IV (Table 3), which were indifferent as far as their distributions along the sediment gradient is concerned, play an important role.

The results of quantitative and qualitative cluster analyses have been viewed for distribution of relevees in time and space (Fig. 10A, B). The quantitative cluster analysis (Fig. 10A) shows that the relevees belonging to Cluster group 1 (composed of Clusters A, B, C and $D$; closed symbols) were found during the first half of the year, whereas the relevees of Cluster group 2 (composed of Clusters $E, F, G$ and $I_{i}$ open symbols) were found in the second half of the year. Cluster $G$ was exclusive to the winter months. Figure 10A further reveals a subdivision into 2 groups along the sediment gradient: within Cluster group 1 Clusters $C$ and D at Stations 2, 4, and 6 , and Clusters A and B at Stations 10 , $8,13(a)$, and 12, respectively. Within Cluster group 2 the same holds true, with small exceptions: Cluster E at Stations 2, 4, and 6, and Cluster F at Stations 10, 8, $13(\mathrm{a})$, and 12 .

The results obtained by the qualitative analysis (Fig. 10B) resembled those obtained by the quantitative analysis. However, there are also some differences: Again, 2 cluster groups can be distinguished: Cluster group 1, composed of the Clusters 1,2, and 3 (open symbols), and Cluster group 2, composed of the Clusters 4 and 5 (closed symbols). Both Cluster groups were limited in their distribution: Cluster group 1 to Stations $10,8,13(\mathrm{a})$, and 12; Cluster group 2 to Stations 2, 4, and 6 . A distinct difference in the results obtained by the

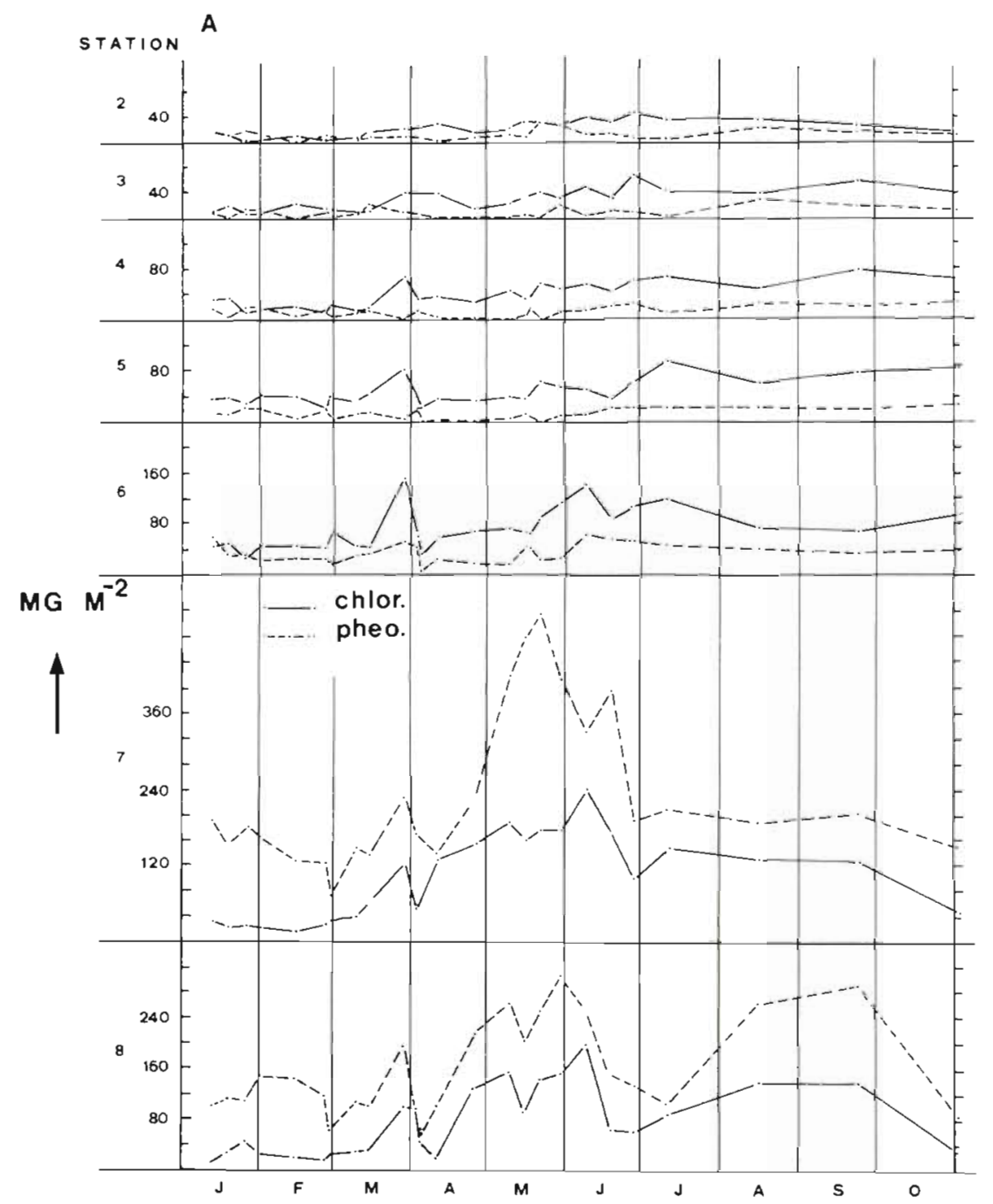

Fig. 6. Concentration of chlorophyll $a$ and pheophytin $\left(\mathrm{mg} \mathrm{m}^{-2}\right)$ at Stations 2-8 in 1973 
qualitative and quantitative analysis is that the cluster groups show different distributional patterns: the quantitative analysis emphasizes the influence of time (first half of the year versus second half of the year), whilst the qualitative analysis emphasizes the influence of the sediment gradient (Stations 2, 4, and 6 , versus Stations 10,8,13a, and 12).

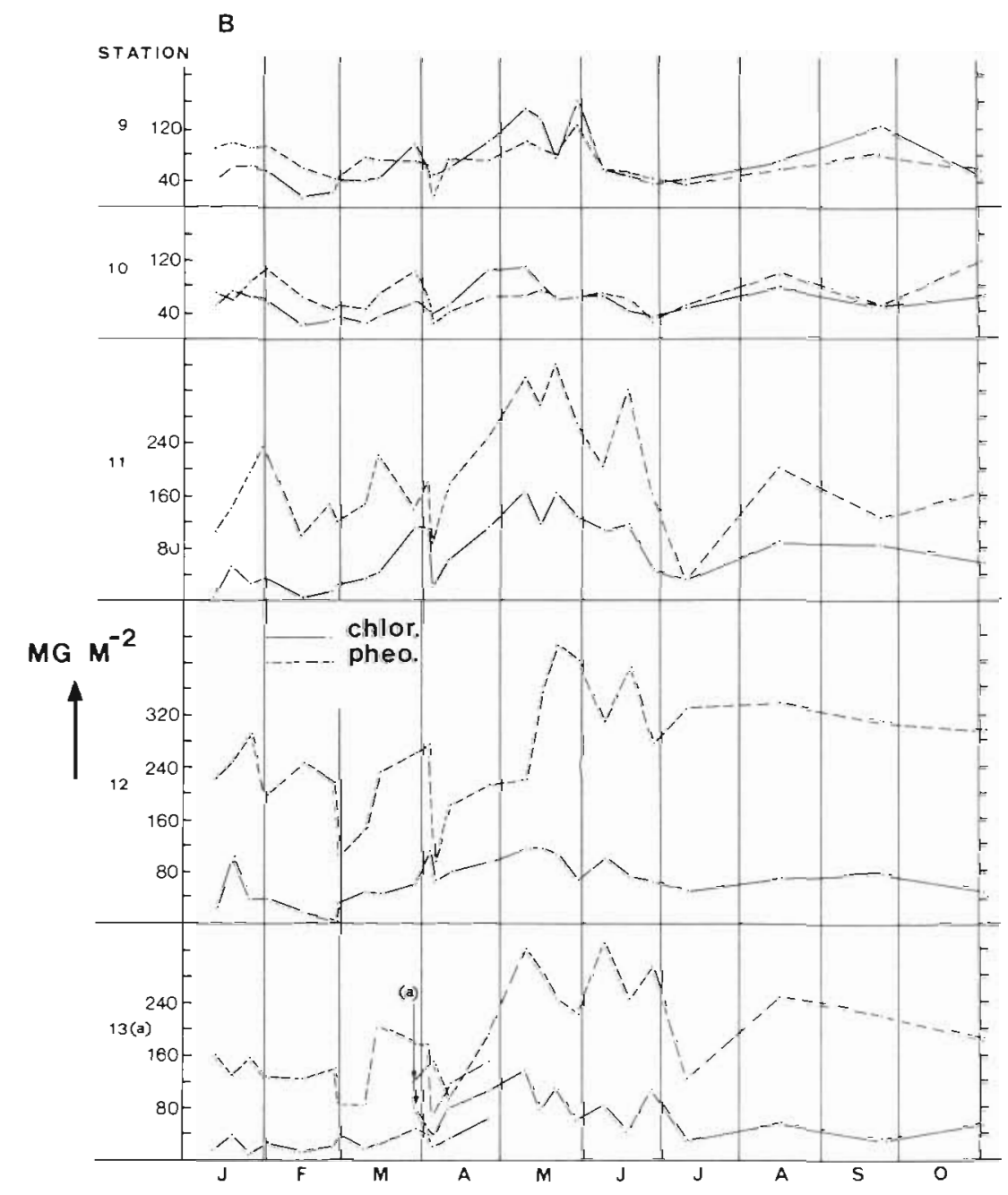

Fig. 7. Concentrations of chlorophyll $a$ and pheophytin $\left(\mathrm{mg} \mathrm{m}^{-2}\right)$ at Stations 9-13 in 1973

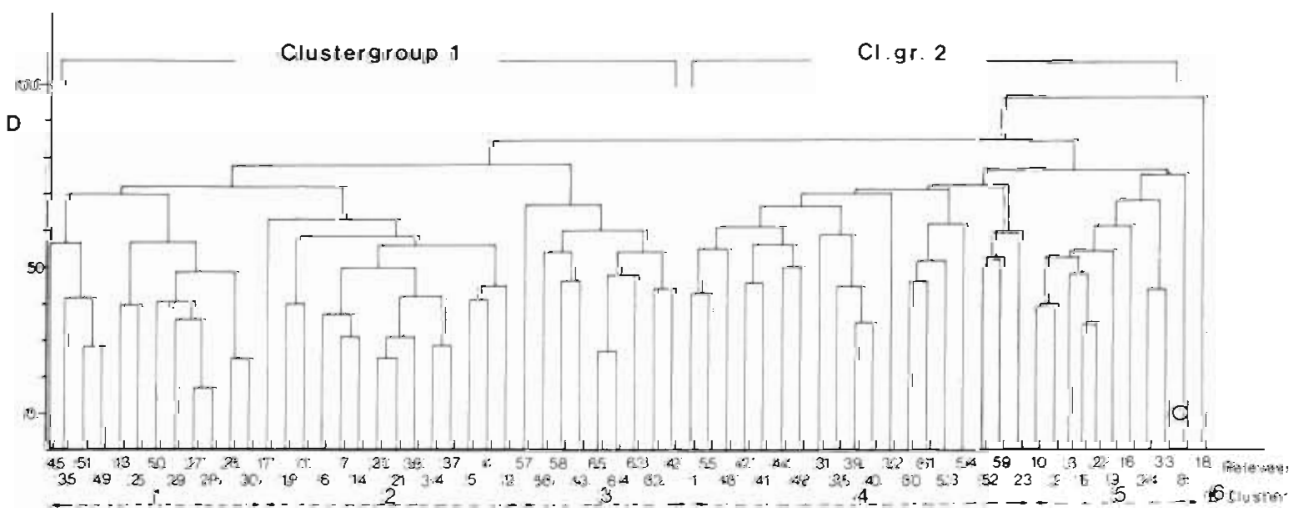

Fig. 8. Dendrogram of relevees from cluster analysis with similarity coefficient $\mathrm{S}_{\mathrm{j}}$ (quantitative data) 


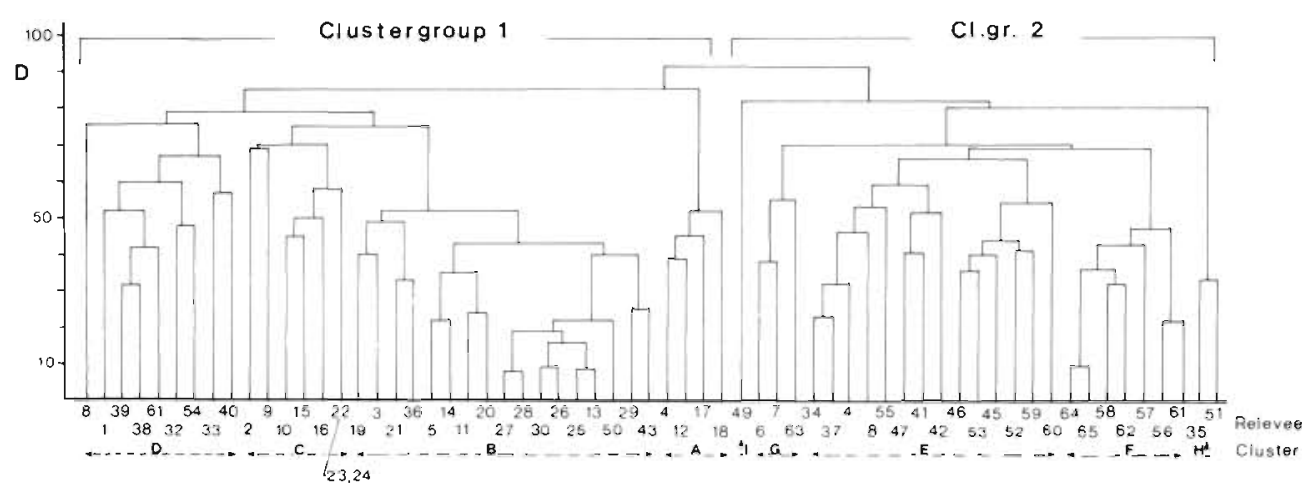

Fig. 9. Dendrogram of relevees from cluster analysis with similarity coefficient $S_{j}$ (qualitative data)
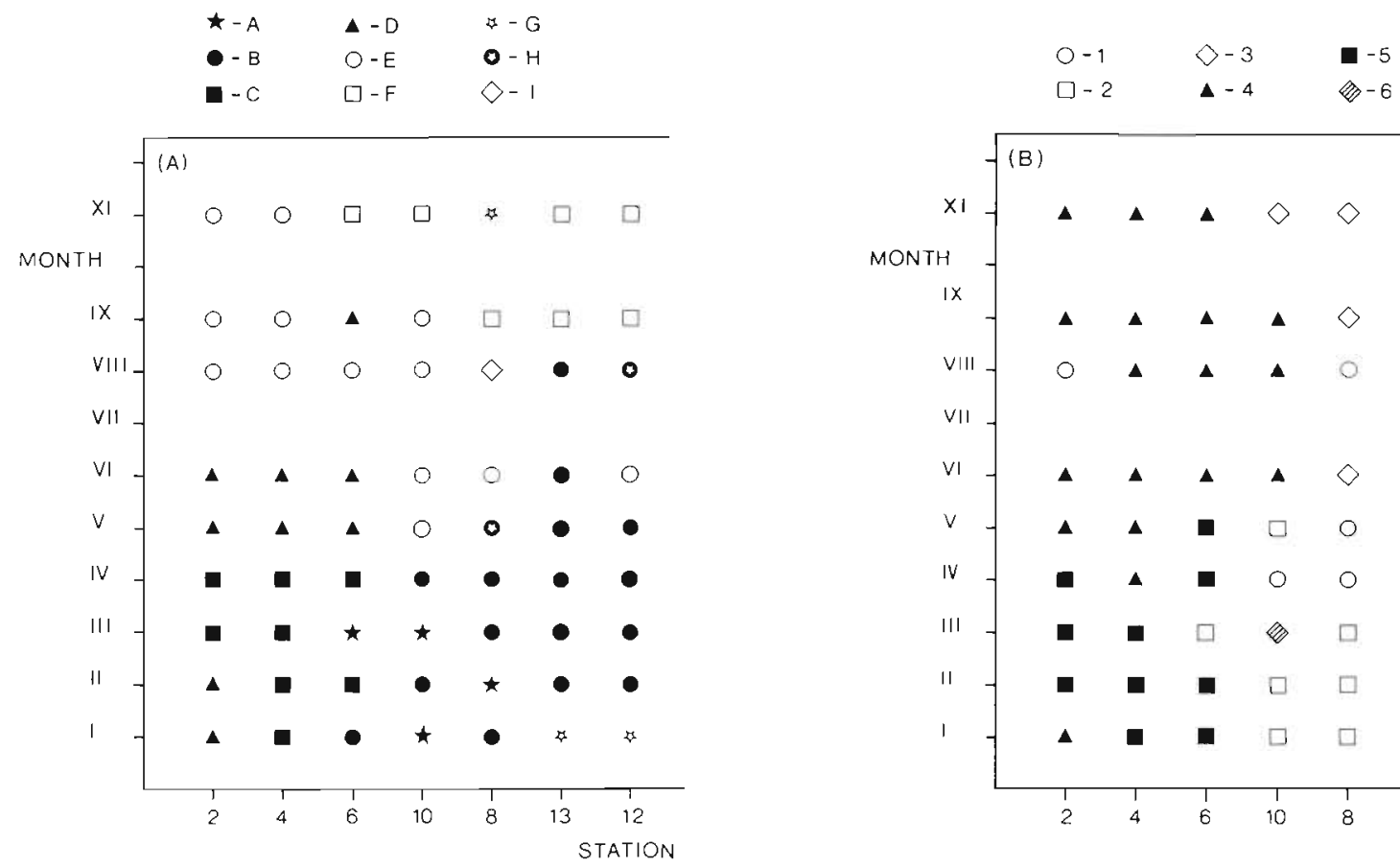

Fig. 10. Distribution in tıme and space of clusters based on quantitative cluster analysis (A) and qualitative cluster analysis (B) $\mathrm{A}-\mathrm{l}$ and $1-6$ refer to clusters (Figs 7 and 8 ). Closed symbols: Cluster group 1; open symbols: Cluster group 2

\section{DISCUSSION}

\section{Algal Pigment Concentrations}

The data given by Cadée and Hegeman (1974 a) for the western Dutch Wadden Sea show a range of 35 to $435 \mathrm{mg}$ chlorophyll a $\mathrm{m}^{-2}$ over a 5 -year period, with an average value of ca $120 \mathrm{mg}$ chlorophyll a, measured over the top $\mathrm{cm}$ of sediment. The average value in the present study, where the top $2 \mathrm{~cm}$ of sediment were sampled, amounted to $65 \mathrm{mg}$ chlorophyll a $\mathrm{m}^{-2}$. Thus, our value is lower than that given by Cadée and Hegeman. Moreover, when we include the verticaldistribution data of Cadée and Hegeman (1974a), which show only a small decrease in chlorophyll a concentration in the second centimeter, the conclusion can be drawn that our chlorophyll a values are much lower.

In a more recent paper (1977) Cadée and Hegeman report both primary production and chlorophyll a data from a tidal flat area (Balgzand) with distinct gradients in sediment composition. Mean yearly values for their 4 transects (D-A, within this sequence an increasing clay content of the sediment) increase from 3.3 to $10.9 \mu \mathrm{g}$ chlorophyll $\mathrm{a} \mathrm{g}^{-1}$ dry sediment. A conversion of these data to $\mathrm{mg}$ chlorophyll a $\mathrm{m}^{-2}$ can be made by multiplying with a factor of 17 (cf. Table 3, Cadée and Hegeman, 1977). In this way, for the 4 transects (D to A) 
mean values of $56,126,83$, and $185 \mathrm{mg}$ chlorophyll a $\mathrm{m}^{-2}$ have been calculated for the top $\mathrm{cm}$. A tendency to obtain higher values in more sheltered places is suggested. The pheopigment values at Stations 12 and 13 a are high compared with those from the Balgzand area (Transect A), even if we take into account sampling depth. These high pheopigment data result in a high pheophytin/chlorophyll a ratio. This high ratio probably indicates a high amount of (algal) detritus close to the coast (cf. Cadée and Hegeman, 1977). In fact, Stations 12 and 13(a) are closest to the land reclamation area where fine-grained sediments, including dead phytoplankton cells (Colijn, 1974), settle.

The mean chlorophyll a values $(30-110 \mathrm{mg}$ chlorophyll $\mathrm{a} \mathrm{m}^{-2}$ ) are comparable to the values found by Riznyk and Phinney (1972) in Yaquina Bay, Oregon, USA, which amounted to ca 30 to $200 \mathrm{mg}$ chlorophyll a $\mathrm{m}^{-2}$ at a sampling depth of $1.3 \mathrm{~cm}$. Low 'total' chlorophyll a values $\left(0-20 \mu \mathrm{g} \mathrm{g}^{-1}\right.$ dry sediment for the top $2 \mathrm{~cm}$ sediment layer) given by Steele and Baird (1968) for an exposed sandy beach agree with lower values at our most seaward stations $(2,3$, and 4$)$. More chlorophyll a concentration data from comparable habitats have been presented by Colijn and Nienhuis (1978; see their Table 6).

Seasonal variation with high values in spring and early summer, as observed by us, was not mentioned by Cadée and Hegeman (1974a). However, a clear summer depression is shown in their Figure 10 B. Over the years, their maximum chlorophyll $a$ values are also bound rather strictly to late spring (April, May, June) and to late autumn (October). Leach (1970) and Pamatmat (1968) found little seasonal variation in comparable habitats. We think that the large fluctuations in the course of 1973 along our transect are seasonal fluctuations, since comparable fluctuations (spring and autumn peaks, summer depression) were encountered in the direct vicinity of our transect (Colijn, 1974).

We have attempted to relate major changes in chlorophyll a concentrations with abiotic factors. During winter (January, February, November) the maximum chlorophyll a values are positively related to the station level, and thus to emersion time (Van den Hoek et al., 1979; Admiraal and Peletier, 1980). During this season light intensity can limit photosynthesis, as it may be below the saturation value (ca $200 \mu \mathrm{E} \mathrm{m}^{-2} \mathrm{~s}^{-1}$; Colijn and Van Buurt, 1975). In winter, the photoperiod is reduced to the tidal emersion time. Hence, in winter the mean photoperiod for benthic diatoms amounts to about half the actual daylength. In summer, with long days and saturating light intensities, the photoperiod may be up to 2 or 3 times the photoperiod in winter. Admiraal (1977) has calculated the quantum irradiance during winter from energy measurements $\left(\mathrm{J} \mathrm{cm}^{-2} \mathrm{~d}^{-1}\right)$. We compared the data in Figure $3 \mathrm{~A}$ and $\mathrm{F}$ with minimum light requirements for growth in culture (ca $5 \mathrm{E} \mathrm{m}^{-2} \mathrm{~d}^{-1}$, equal to $125 \mathrm{~J} \mathrm{~cm}^{-2} \mathrm{~d}^{-1}$; cf. Admiraal, 1977). On most days during January and February the total sky irradiance did not exceed $250 \mathrm{~J} \mathrm{~cm}^{-2}$. When we reduce this value by a factor 2 to obtain the effective irradiance (ca $125 \mathrm{~J} \mathrm{~cm}^{-2}$ ), we obtain limiting light intensities on almost every day. However, we must keep in mind that we have compared growth rate with photosynthetic rate, which are different variables. Anyhow, the more elevated position of the Stations 4 , $5,6,9$, and 10 (Fig. $4 \mathrm{~B}$ ) is more favourable for growth in winter. Indeed, a significant positive correlation $(\mathrm{r}=$ $0.57, \mathrm{n}=60$ ) was found between chlorophyll a concentration and the effective irradiance in January and November. The latter was calculated as the product of global radiation between the sampling dates and emersion time. Grøntved (1962), Pomeroy (1959), Pamatmat (1968) and Cadée and Hegeman (1974a) have reached similar conclusions.

During the rest of the year (March till October) the stations which were most sheltered against currents and waves, namely Stations 7 and 8, showed the highest chlorophyll a values; no positive or negative effect of elevation could be demonstrated.

The negative effects of bad weather could be demonstrated on several occasions, mostly through direct observations in the field: a storm rising on April 2 during sampling diminished the spring bloom to a considerable degree. However, the decrease in chlorophyll a values from 150 to $40 \mathrm{mg}$ chlorophyll $a$ $\mathrm{m}^{-2}$ at Station 6 was caused by the preceding heavy rainfall during emersion (Figs 6 and 7 ; sampling: April 2). Also at Stations $4,5,7,9,10$, and 13 a distinct decrease was found. The diatom vegetation at Stations 8 and 11 was not yet affected, because it was protected by a water layer; at Station 12 the diatom film was still cohering with the sediment, although rain drops had caused pits. The washing away of diatoms by severe wave action caused by the storm itself was documented most clearly at Station 12 where both chlorophyll $a$ and pheopigment values were lowered appreciably just after this storm (Figs 6 and 7 : sampling April 4). Similar observations were made after a storm in mid February which caused a decrease in chlorophyll $a$ and pheophytin values at Stations 9, 10, and 11. The decrease on May 15 could not be explained from any of the abiotic factors measured. We conclude that hard winds with rain and heavy sea rupture the coherent sediment layer stabilized by a film of diatoms (Van der Werff, 1960; Holland et al., 1974) and resuspend benthic diatoms. This phenomenon explains the occasionally high numbers of benthic diatoms in the phytoplankton of the Wadden Sea (Grontved, 1960; Cadée and Hegeman, 1974b). The negative effect on the diatom vegetation by heavy 
rainfall alone was mentioned earlier by Williams (1962) and König (1970).

The cause of the summer depression is unknown. It seems unlikely that it is due to photosynthetic inhibition by high light intensities. Several authors (Taylor, 1964; Pamatmat, 1968; Cadée and Hegeman, 1974 a; Colijn and Van Buurt, 1975) provided evidence for a high tolerance of benthic diatoms against high light intensities.

\section{Epipelic Species Composition}

The results of the cluster analysis clearly show that the epipelic benthic diatoms are differentially distributed along the sediment gradient, which corresponds to the exposure gradient, and along the time axis (Fig. 10A, B). The quantitative (Fig. 10A) and qualitative (Fig. 10B) cluster analyses show both differences and similarities. The number of clusters distinguished in both analyses are subjective and based merely on the delimitation of the distance (D). In the quantitative analysis the small clusters (A, G, H, and I) contained only one dominant species that was very abundant. Naturally, this type of cluster will not be found in the qualitative analysis.

A rather sharp boundary between the vegetations of Stations 2, 4, and 6 and those of Stations 10,8,13, and 12 is strongly suggested by the cluster-group distributions obtained from the qualitative analysis in Figure $10 \mathrm{~B}$. It is supposed that this qualitative analysis is a better means to relate species composition to sediment composition than the quantitative analysis. In the quantitative analysis the distribution of cluster groups reveals effects of station and of time. Occasionally blooming species cause the more pronounced changes along the time axis.

When the number of clusters shared by one station is used as a measure for 'cluster stability' at a given station, a high cluster stability is demonstrated for Stations 2, 4, 10, 12, and 13(a), but a low cluster stability for Stations 6 and 8 (Fig. 10A). We suppose that this measure for the stability at a given station is partly related to the relatively uniform composition of the sediment of the stations throughout the year, but this hypothesis requires confirmation based on a more prolonged analysis of the living benthic flora, comprising both epipelic and epipsammic diatoms.

We shall now discuss our results in view of those obtained from other, comparable areas. Studies on the influence of abiotic factors on attached diatorn assemblages in Yaquina Bay (McIntire and Overton, 1971; McIntire, 1973) show that salinity and intertidal exposure influence the species composition of the assemblages concerned. Sullivan (1975) studied the epipelic diatom vegetations of 5 different salt marsh habitats and concluded that differences between communities were closely related to differences in temperature and level. Although this latter study extended over 1 year, seasonal variations in species composition are not mentioned. On the Knechtsand and the Hohe Weg, vast shallows in the German Southern Wadden Sea, the tidal level is the main factor responsible for the differentiation of the benthic diatom vegetation. Three cluster groups correspond with 3 tidal levels, namely the upper, middle and lower eulittoral level. Within each eulittoral level the clusters can be arranged along a West-East axis, which probably corresponds to an exposure gradient (Colijn and Koeman, 1975; Colijn and Nienhuis, 1978; Van den Hoek et al., 1979). Van der Werff (1960) investigated a transect not far from our transect; his Table 3 suggests a differential distribution of benthic diatoms along an exposure-gradient. Brockmann (1950) distinguishes 3 communities, each characteristic for a sediment type; his results are consistent with our observations. However, his communities are based on 31 samples in total, and it is unlikely that the benthic diatom vegetations of the Wadden Sea can be subdivided into only 3 communities. Rather, benthic diatom vegetations seem to change continuously along the environmental gradients and along the time axis. Only prolonged series of observations can be expected to disclose a potential seasonality in temporal species-composition changes along our gradient.

\section{Comparison of Chlorophyll Values and Species Composition}

The species abundances in the synoptic table show that 11 out of 65 relevees (distributed over 8 dates) are dominated by a single species (abundance $>50 \%$ ). All these species, except one, belong to Category IV (indifferent in their spatial distribution). Nine of these relevees coincided with high chlorophyll values. It seems that the high biomass values found in benthic diatom vegetations are formed almost exclusively by single species.

Acknowledgements. We thank W. Admiraal, Professor Dr. C. van den Hoek, and Dr. P. de Wolf for critically reading the manuscript. L. A. F. M. Fresco made the computer program available; this assistance is greatly appreciated.

\section{LITERATURE CITED}

Admiraal, W. (1977). Influence of light and temperature on the growth rate of estuarine benthic diatoms in culture. Mar. Biol. 39: 1-9 
Admiraal, W., Peletier, H. (1980). Influence of seasonal variations of temperature and light on the growth rate of cultures and natural populations of intertidal diatoms. Mar Ecol. Prog. Ser. 2: 35-43

Brockmann, C. (1950). Die Watt-Diatomeen der schleswigholsteinischen Westküste. Abh. senckenb. naturforsch. Ges. 478: 1-26

Cadée, G. C., Hegeman, J. (1974 a). Primary production of the benthic microflora living on tidal flats in the Dutch Wadden Sea. Neth. J. Sea Res. 8: 260-291

Cadée, G. C., Hegeman, J. (1974 b). Primary production of phytoplankton in the Dutch Wadden Sea. Neth. J. Sea Res. 8: $240-259$

Cadée, G. C., Hegeman, J. (1977). Distribution of primary production of the benthic microflora and accumulation of organic matter on a tidal flat area, Balgzand, Dutch Wadden Sea. Neth. J. Sea Res. 11: 24-41

Colijn, F. (1974). Biomassa, primaire produktie en soortensamenstelling van benthische diatomeeën op het Groninger Wad, Dept. of Systematic Botany, Haren, The Netherlands (mimogr, report)

Colijn, F., van Buurt, G. (1975). Influence of light and temperature on the photosynthetic rate of marine benthic diatoms. Mar. Biol. 31: 209-214

Colijn, F., Koeman, R. (1975). Das Mikrophytobenthos der Watten, Strände und Riffe um den Hohen Knechtsand in der Wesermündung. Forschungsstelle Norderney, Jahresbericht 1974, XXVI: 53-83

Colijn, F., Nienhuis, H., de Jonge, V. N., Koeman, R. P. T (1976). Distribution and seasonal periodicity of sediment inhabiting benthic diatoms in the Waddensea and the Ems-Dollard estuary. Acta bot. neerl. 25: 122-123

Colijn, F, Nienhuis, H. (1978). The intertidal microphytobenthos of the 'Hohe Weg' shallows in the German Wadden Sea. Forschungsstelle Norderney, Jahresbericht 1977 , XXIV: $149-174$

Dijkema, K. S. (1975). Verkennend onderzoek naar de invloed van abiotische factoren op de benthische diatomeeën in de Oostelijke Waddenzee. Biologisch Onderzoek Veenkoloniaal Afvalwater 1975-4 (mimeogr. report, P. O. Box 59, Texel, The Netherlands)

Eaton, J W., Moss, B. (1966). The estimation of numbers and pigment content in epipelic algal populations. Limnol. Oceanogr 11.584-595

Essink, K. (1978). The effects of pollution by organic waste on macrofauna in the Eastern Dutch Wadden Sea. Neth. Institute for Sea Research, Publication Series 1: 1-135

Goodall, D. W (1973a). Sample similarity and species correlation. In: Whittaker, R. H. (ed.) Handbook of vegetation science, Vol. V, Ordination and classification of communities. Junk, Den Haag

Goodall, D. W (1973b). Numerical classification. In: Whit taker, R. H. (ed.) Handbook of vegetation science, Vol. V. Ordination and classification of communities. Junk, Den Haag

Grontved, J. (1960). On the productivity of microbenthos and phytoplankton in some Danish fjords. Meddr Danm. Fisk. og Havunders. 3: 55-92

Grentved, J. (1962). Preliminary Report on the productivity of microbenthos and phytoplankton in the Danish Wadden Sea. Meddr Danm. Fisk.- og Havunders. 3: 347-378

Held, J. J. den, Held, A. J. den (1973). Beknopte handleiding voor vegetatiekundig onderzoek. Wet. Meded. K. ned natuurh. Veren. 97: 1-40

Hoek, C. van den, Admiraal, W., Colijn, F., Jonge, V N. de (1979). The role of algae and seagrasses in the ecosystem of the Wadden Sea: a review. In: Wolff, W. J. (ed.) Flora and vegetation of the Wadden Sea. Wadden Sea Working Group, Report 3: 8-118

Holland, A. F., Zingmark, R. G., Dean, J. M. (1974). Quantitative evidence concerning the stabilization of sediments by marine benthic diatoms. Mar. Biol. 27: 191-196

Holland, R. E., Claflin, L. W (1975). Horizontal distribution of planktonic diatoms in Green Bay, mid-July 1970. Limnol. Oceanogr. 20: 365-378

Hustedt, F. (1939). Die Diatomeenflora des Küstengebietes der Nordsee vom Dollard bis zur Elbemündung, Teil 1 Abh. naturw. Ver. Bremen 31: 572-677

Jonge, V. N. de (1979). Quantitative separation of benthic diatorns from sediments using density gradient centrifugation in the colloidal silica Ludox-TM. Mar. Biol. 51: $267-278$

König, D. (1970). Diatom investigations at the West Coast of Schleswig-Holstein. In: Simonsen, R. (ed.) Proceedings of first symposium on recent and fossil marine diatoms, 1970. Beih. Nova Hedwigia 39: 127-137

Leach, J. H. (1970). Epibenthic algal production in an intertidal mudflat. Limnol. Oceanogr 15: 514-521

Linke, O. (1939). Die Biota des Jadebusenwattes. Helgoländer wiss. Meeresunters. 1: 201-348

Lorenzen, C. J. (1967). Determination of chlorophyll and pheopigments: spectrophotometric equations. Limnol. Oceanogr. 12: 343-346

Manuels, M. V., Rommets, J. W. (1973). Metingen van zoutgehalte, temperatuur en zwevend materiaal in de Waddenzee, april 1970-Oktober 1972. NIOZ, interne publicatie 1973-6 (mimeogr. report, P. O. Box 59, Texel, The Netherlands)

Marshall, N., Oviatt, C. A., Skauen, D. M. (1971). Productivity of the benthic microflora of shoal estuarine environments in Southern New England. Int. Revue ges. Hydrobiol. 56: 947-956

McIntire, C. D. (1973). Diatom associations in Yaquina estuary, Oregon: a multivariate analysis. J. Phycol. 9: 254-259

McIntire, C. D., Overton, W. S. (1971). Distributional patterns in assemblages of attached diatoms from Yaquina estuary, Oregon. Ecology 52: 758-777

Pamatmat, M. M. (1968). Ecology and metabolism of a benthic community on an intertidal sandflat. Int. Revue ges. Hydrobiol. 53: 211-298

Pomeroy, L. R. (1959). Algal productivity in salt marshes of Georgia. Limnol. Oceanogr. 4: 386-397

Riznyk, R. Z., Phinney, H. K. (1972). Distribution of intertidal phytopsammon in an Oregon estuary Mar. Biol. 13: 318-324

Steele, J. H., Baird, I. E. (1968). Production ecology of a sandy beach. Limnol. Oceanogr. 13: 14-25

Sullivan, M. J. (1975). Diatom communities from a Delaware salt marsh. J. Phycol. 11: 384-390

Taylor, W. R. (1964). Light and photosynthesis in intertidal benthic diatoms. Helgoländer wiss. Meeresunters. 10 $(1-4): 29-37$

Walkley, A., Black, H. A. (1934). An examination of the Degtjareff method for determining soil organic matter, and a proposed modification of the chromic acid and titration method. Soil Sci. 37: 29-38

Werff, A. van der (1960). Die Diatomeen des Dollart-Emsgebietes. Verh. K. ned. geol-mijnb. Genoot. (Geol. Serie D 19)

Westhoff, V., van der Maarel, E. (1973). The Braun-Blanquet approach. In: Whittaker, R. H. (ed.) Handbook of vegetation science, Vol. V. Junk, Den Haag 
Williams, R. B. (1962). The ecology of diatom populations in a Georgia salt marsh. Ph. D. thesis, Harvard University, Cambridge
Wolf, P. de (1977). 'Biologisch Onderzoek Veenkoloniaal Afvalwater': an introduction and a review of a wastewater research project. Hydrobiol. Bull. 11: $7-11$

This paper was submitted to the editor; it was accepted for printing on November 15, 1980 